\author{
ACTA MYCOLOGICA \\ Vol. 47 (1): 21-26 \\ 2012
}

\title{
Cercospora berteroae and Pseudocercosporella gei, rare anamorphic fungi
}

\author{
EWA POŁEĆ and MAŁGORZATA RUSZKIEWICZ-MICHALSKA \\ Department of Mycology, Faculty of Biology and Environmental Protection \\ University of Łódź, Banacha 12/16, PL-90-237 Łódź, ewa_polec@op.pl
}

Połeć E., Ruszkiewicz-Michalska M.: Cercospora berteroae and Pseudocercosporella gei, rare anamorphic fungi. Acta Mycol. 47 (1): 21-26, 2012.

The paper presents two species of hyphomycetous fungi, presumably Mycosphaerella anamorphs, recently collected in central and north-eastern Poland. Habit and morphology, illustrated with macro- and microphotographs, and worldwide distribution of the species are characterized. Both species have been collected in Poland for the first time.

Key words: microfungi, Mycosphaerella, hyphomycetes, parasites, Berteroa, Geum, Poland

\section{INTRODUCTION}

The genera Cercospora and Pseudocercosporella belong to the Cercosporella/Ramularia complex, which groups 26 genera of colourless or very pale hyphomycetes with holoblastic conidiogenesis (Braun 1995). The known teleomorphs of Cercospora and Pseudocercosporella belong to the ascomycetous genus Mycosphaerella s.l. (Braun 1995; Crous, Braun 2003).

The genus Cercospora was introduced by Fresenius in 1863 for the Passalora-like species with pluriseptate conidia (Crous, Braun 2003). Many members of the genus are important plant pathogens and often major agents of crop losses worldwide. They occur on a wide range of hosts and can be associated with angiosperms as well as with some gymnosperms and ferns (To-Anun, Hidayat, Meeboon 2011). Some species are hyperparasites of rust fungi, e.g., Passalora acori (J. M. Yen) U. Braun \& Crous, parasitizing the uredospores of Uromyces sparganii Cooke \& Peck (Shin, Kim 2001). According to the recent taxonomic studies of the Cercospora species in Thailand, the genus is considered to be monophyletic (To-Anun et al. 2011).

The members of the Pseudocercosporella genus are phytopathogens mostly causing leaf spots (Shin, Kim 2001). The genus was established by Deighton over one 
hundred years after Cercospora for the species characterized by unthickened, inconspicuous conidial scars. Later Braun (1990) narrowed the genus to species with solitary conidia and transferred the taxa with catenate conidia to Thedgonia. According to the molecular studies of Crous et al. (2012) the genus resides in a large clade together with Cercospora, Miuraea, Phloeospora, Septoria and Xenocercospora.

Despite the fact that many members of the Cercosporella/Ramularia complex are economically important pathogens of major agricultural crops this group of anamorphic fungi is still insufficiently known worldwide (Shin, Kim 2001; Bakhshi, Arzanlou, Babai-Ahari 2012; To-Anun et al. 2011). The recently published preliminary list of cercosporoid hyphomycetes known from Poland covers 32 species of the genus Cercospora and 31 belonging to Passalora (Świderska-Burek 2007). Lately, the number of cercosporoid fungi known in the country has been expanded with Passalora acericola (Liu \& Guo) U. Braun \& Crous (Świderska-Burek, Mułenko 2010). According to the checklist of Polish micromycetes only 6 Pseudocercosporella species have been noted in Poland so far (Świderska-Burek 2008).

\section{MATERIAL AND METHODS}

The original materials with plant organs affected by anamorphic fungi were collected in the urbicoenoses of Łódź city and a single specimen originates from Biebrza National Park. The fresh specimens mounted in lactophenol picric acid solution (Fluka) were examined using the microscope Nikon Eclipse E200; measurements of the morphological structures were made also in tap water. Microphotographs of morphological structures of the species were taken with a Nikon DS-F1 digital camera. The fungal nomenclature follows Crous and Braun (2003) and the host plants nomenclature is given after Mirek et al. (2002).

The vouchers are deposited in the Herbarium Universitatis Lodziensis (LOD) in the collection of parasitic fungi labelled as PF.

\section{RESULTS}

As the result of mycocoenological research in urbicoenoses of the Łódź city two species of anamorphic fungi new for the Polish mycobiota were identified, namely Cercospora berteroae Hollós and Pseudocercosporella gei (Farl.) U. Braun. The first was primarily collected on Berteroa incana (L.) DC. in one of the city parks and further on Geum urbanum L. in the Las Łagiewnicki nature reserve. 


\section{DESCRIPTION OF THE SPECIES}

Cercospora berteroae Hollós, Ann. Mus. Nat. Hung. 5: 468 (1907)

Leaf spots amphigenuous, circular or irregular, up to $2.0 \mathrm{~mm}$ wide, pale yellow to ochraceous, margin dark (Fig. 1A). Caespituli amphigenuous, conidiophores in loose to fairly dense fascicles, arising from stromata, simple, straight, erect, smooth, pale yellow to medium brown, darker brown at the base, not branched 65-75 x $5 \mu \mathrm{m}$, conidiogenous loci thickened and darkened. Conidia solitary, narrowly obclavate, straight, 2-6-septate, hyaline, smooth, truncate at the base, $45-75 \times 3.75-5 \mu \mathrm{m}$, hila

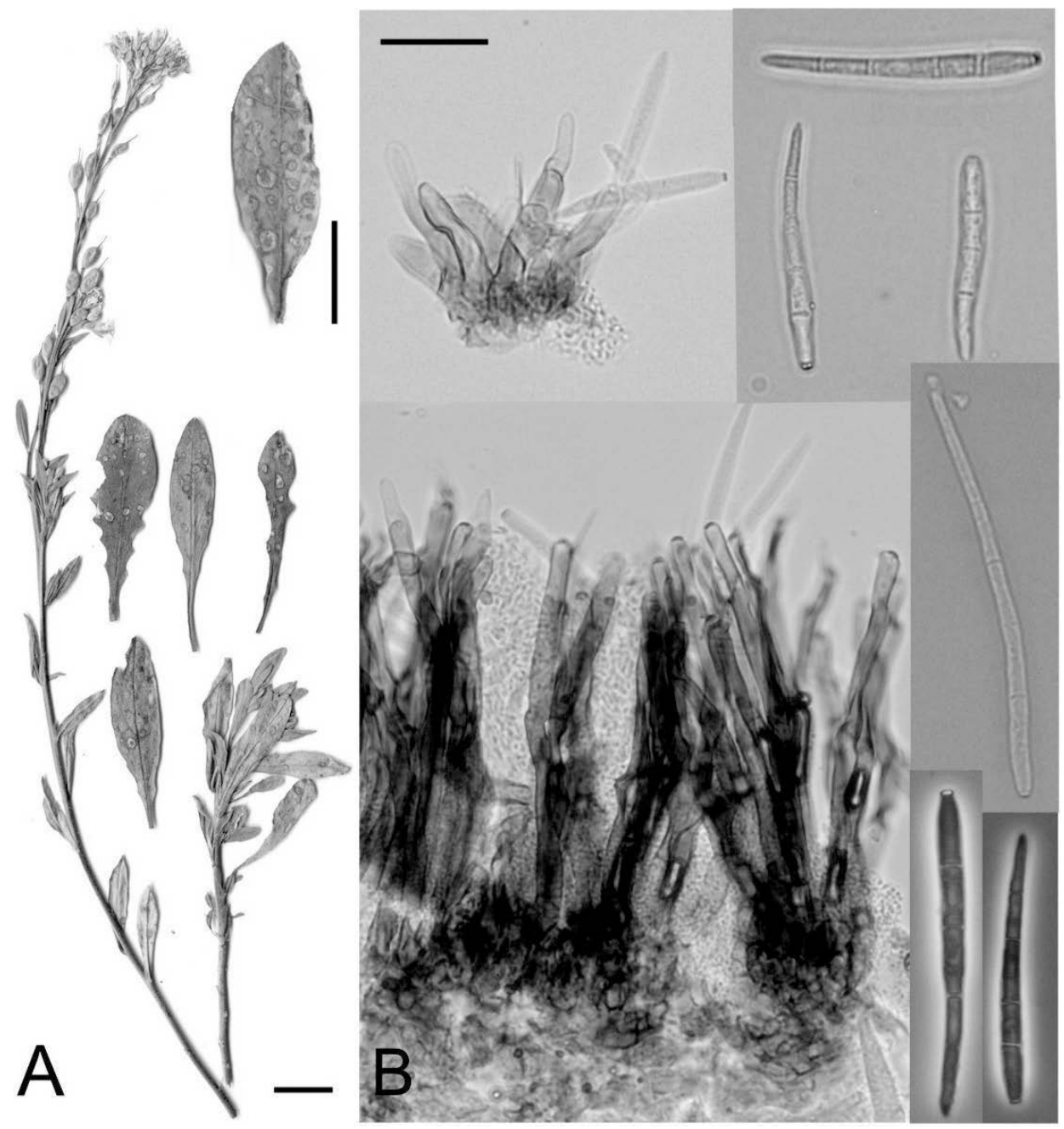

Fig. 1. Cercospora berteroae (LOD $3387 \mathrm{PF):} \mathrm{A} \mathrm{-} \mathrm{host} \mathrm{plants} \mathrm{with} \mathrm{syptoms} \mathrm{of} \mathrm{fungal} \mathrm{infection}$ visible on the leaves; $\mathrm{B}$ - conidiophores and conidia (lactophenol picric acid solution; phase contrast). Scale bars: $\mathrm{A}=1 \mathrm{~cm} ; \mathrm{B}=20 \mu \mathrm{m}$. 


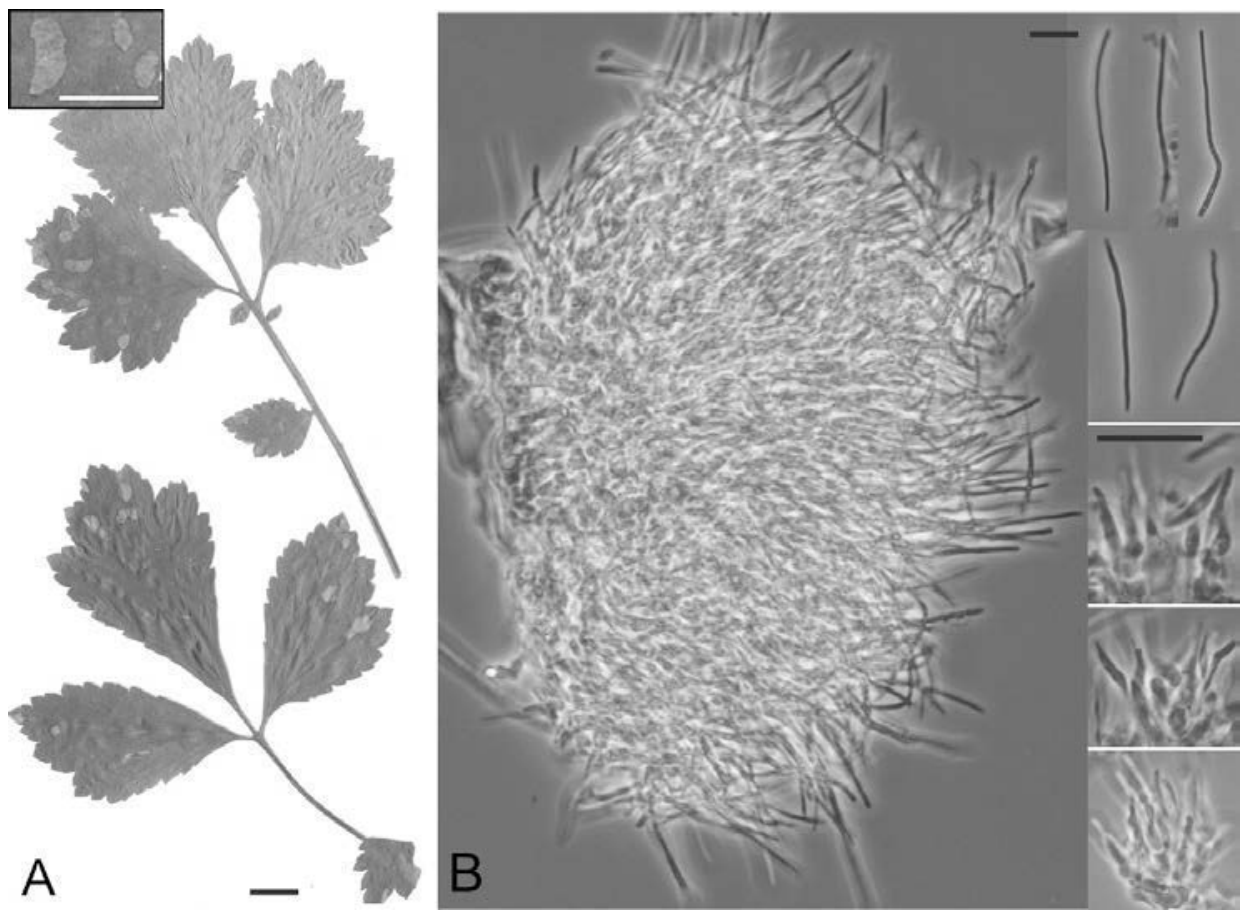

Fig. 2. Pseudocercosporella gei (LOD 3388 PF): A - lower leaves of a host plant with syptoms of fungal infection; $\mathrm{B}$ - conidiophores and conidia (lactophenol picric acid solution; phase contrast). Scale bars: $\mathrm{A}=1 \mathrm{~cm} ; \mathrm{B}=20 \mu \mathrm{m}$.

thickened, darkened (Fig. 1B). Morphological features of the specimens generally correspond to those described by Chupp (1954, accessed at www.mycobank.org).

Material examined. On Berteroa incana (L.) DC, Central Poland, Łódź, "Park im. Bolesława Chrobrego" park, 12 Oct. 2006, leg. D. Papierz, LOD 3026 PF; NE Poland, Biebrza National Park, Obwód ochronny Grzędy district, inland dune, sandy grassland, 30 Aug. 2012, leg. M. Ruszkiewicz-Michalska, LOD 3387 PF.

Notes. The species is known only on Berteroa incana (Brassicaceae) from Europe (Hungary, Lithuania, Russia and Ukraine) and North America (USA: Wisconsin) (Crous, Braun 2003; Farr, Rossman 2012).

Pseudocercosporella gei (Farlow) U. Braun, Nova Hedwigia 50: 504 (1990)

Leaf spots amphigenous, subcircular or angular, up to $6.0 \mathrm{~mm}$ in diam., pale yellowish to pale greenish, margin purple, narrow, indistinct (Fig. 2A). Caespituli epiphyllous, greyish white, punctiform. Mycelium internal, forming dense stromata, pale yelowish to pale brownish. Conidiophores in dense fascicles, arising from stromata, simple, straight or sometimes curved, subcylindric to slightly geniculate-sinuous, 12.5-25 x 2.5-3 $\mu \mathrm{m}$, aseptate, hyaline, smooth, conidial scars inconspicuous. Conidia solitary, filiform-acicular, 37.5-112.5 x 2.5-3 $\mu \mathrm{m}, 1$-4-septate, hyaline, smooth, rounded to truncate at the base (Fig. 2B). Morphological features of the specimen generally correspond to those given by Braun (1995).

Material examined. On Geum urbanum L., Central Poland, Łódź, Las Lagiewnicki reserve, forest roadside, 02 July 2011, leg. A. Ozimek, LOD 3388 PF. 
Notes. The species has been reported on the members of Geum L. (Rosaceae) from Asia and North America. It was associated with Geum aleppicum Jacq. (Asia, Russia), G. radiatum Michx. and G. strictum Ait. (North America) (Braun 1995; Farr, Rossman 2012).

\section{FINAL REMARKS}

The presented findings of two new species for Poland were the result of studies carried out of in the Łódź city, the area greatly subjected to anthropopression. However, Cercospora berteroae has been also subsequently confirmed at the protected area in Biebrza National Park. Both fungal species were found on common plant species, which are often parasitized by other micromycetes in Poland (Mułenko, Majewski, Ruszkiewicz-Michalska 2008). On Berteroa incana only biotrophic parasites were recorded, e.g., Albugo candida (Pers.) Kuntze, Peronospora berteroae Gäum. and Erysiphe cruciferarum Opiz ex Junell. Geum urbanum is known to host Peronospora gei H. Syd., Sphaerotheca aphanis (Wallr.) U. Braun, and two species classically referred to as Mycosphaerella anamorphs (e.g., Ramularia gei (Elliasson) Lindr. and Septoria gei Roberge ex Desm.).

Although Cercospora and Pseudocercosporella have traditonally been linked to the ascomycetous genus Mycosphaerella s.l. (Crous, Braun 2003), the teleomorphs of the majority of cercosporoid fungi are still unknown and a Mycosphaerella state has been proven only for few species (Bakhshi et al. 2012). Both species reported here have no known teleomorphic connections. There are no Mycospharella taxa connected with Berteroa species (Aptroot 2006) while four species are known to be parasites of Geum: Sphaerella geicola Kalchbr. \& Cooke, Mycospharella koldingensis Munk, M. larsenii Munk, and M. melanoplaca (Dem.) Johanson ex Oudem. However, none of them was reported in Poland so far (Mułenko et al. 2008). Thus, we assume that species represented by anamorphs reported here are new to Polish mycobiota.

\footnotetext{
Acknowledgements. The authors are very grateful to Professor Maria Lawrynowicz, Curator of the Fungal Collection of Herbarium Universitatis Lodziensis (LOD), for permission to analyse herbarium materials. They include specimens collected by Danuta Papierz and Aleksandra Ozimek (MSc students supervised by the second author) whose contribution is greatly acknowledged. We thank Professor Krystyna Czyżewska (University of Łódź) for providing access to microphotographic equipment as well as two anonymous reviewers for their thorough review of the paper and critical remarks. The studies were partially supported by the Ministry of Science and Higher Education (grant no N305 077 32/2708). The first author was also granted in the frame of the project "Scholarships to support innovative doctoral research" by the European Social Fund and the Budget as a part of Integrated Regional Operational Programme in 2010.
} 


\section{REFERENCES}

Aptroot A. 2006. Mycosphaerella and its anamorphs: 2. Conspectus of Mycosphaerella. CBS Biodiversity Series 5: 1-231.

Bakhshi M., Arzanlou M., Babai-Ahari A. 2012. Comprehensive check list of Cercosporoid fungi from Iran. Plant Pathology \& Quarantine 2 (1): 44-55.

Braun U. 1990. Studies on Ramularia and allied genera (III). Nova Hedwigia 50: 499-521.

Braun U. 1995. A monograph of Cercosporella, Ramularia and allied genera (phytopathogenic hyphomycetes). 1. IHW - Verlag, Eching.

Chupp C. 1954. A monograph of the fungus genus Cercospora. Ithaca, New York. Published by the author.

Crous P. W., Braun U. 2003. Mycosphaerella and its anamorphs: 1. Names published in Cercospora and Passalora. CBS Biodiversity Series 1: 1-571.

Crous P. W., Braun U., Hunter G. C., Wingfield M. J., Verkley G. J. M., Shin H.-D., Nakashima C., Groenewald J. Z. 2012. Phylogenetic lineages in Pseudocercospora. Stud. Mycol. 75: 35-114.

Farr D. F., Rossman A.Y. 2012. Fungal Databases, Systematic Mycology \& Microbiology Laboratory, ARS, USDA [Retrieved 13.09.2012, from the Database at: http://nt.ars-grin.gov/fungaldatabases/].

Mirek Z., Piękoś-Mirkowa H., Zając A., Zając M. (eds). 2002. Flowering plants and pteridophytes of Poland. A checklist. (In:) Z. Mirek (ed.). Biodiversity of Poland 1. W. Szafer Institute of Botany, Polish Academy of Sciences, Kraków, 442 pp.

Mułenko W., Majewski T., Ruszkiewicz-Michalska M. (eds). 2008. A preliminary checklist of micromycetes in Poland. (In:) Z. Mirek (ed.). Biodiversity of Poland 9. W. Szafer Institute of Botany, Polish Academy of Sciences, Kraków, 752 pp.

Shin H. D., Kim J. D. 2001. Cercospora and allied genera from Korea. Nat. Inst. Agric. Sci. Tech., Suwon, Korea, 302 pp.

Świderska-Burek U. 2007. Preliminary list of cercosporoid fungi from Poland. Mycotaxon 102: 5-8.

Świderska-Burek U. 2008. Genera Pseudocercospora \& Pseudocercosporella. (In:) W. Mułenko, T. Majewski, M. Ruszkiewicz-Michalska (eds). A preliminary checklist of micromycetes in Poland (In:) Z. Mirek. (ed.). Biodiversity of Poland 9. W. Szafer Institute of Botany, Polish Academy of Sciences, Kraków: 461-462.

Świderska-Burek U., Mułenko W. 2010. Passalora acericola - a rare cercosporoid species found for the first time in Poland. Mycotaxon 113: 351-354.

To-Anun C., Hidayat I., Meeboon J. 2011. Genus Cercospora in Thailand: Taxonomy and phylogeny (with a dichotomous key to species). Plant Pathology \& Quarantine 1 (1): 11-87.

\section{Cercospora berteroae i Pseudocercosporella gei, rzadkie gatunki grzybów anamorficznych}

\section{Streszczenie}

Podczas badań nad pasożytniczymi mikromycetes prowadzonych w granicach aglomeracji łódzkiej stwierdzono występowanie dwóch gatunków grzybów anamorficznych, które nie były wcześniej notowane na obszarze naszego kraju. Są to Cercospora berteroae Hollós pasożytujący na Berteroa incana (L.) DC. i Pseudocercosporella gei (Farl.) U. Braun na Geum urbanum L. Materiał został zebrany w parku im. Bolesława Chrobrego w Łodzi, w rezerwacie Las Łagiewnicki położonym również w granicach miasta oraz w Biebrzańskim Parku Narodowym. W pracy zawarto opisy cech morfologicznych grzybów i prezentujące je mikrofotografie. Zestawiono także dane o ich rozmieszczeniu na świecie. 